\title{
Flotation of mercury from the tailings of the Agh-Darreh gold processing plant, Iran
}

\author{
by Y. Kianinia* , M.R. Khalesi ${ }^{\ddagger}$, A. Seyedhakimi ${ }^{\dagger}$, and \\ F. Soltani*
}

\section{Synopsis}

The feed ore to Agh-Darreh gold processing plant (Takab City, Iran) contains $2 \mathrm{ppm} \mathrm{Au}, 7 \mathrm{ppm} \mathrm{Ag}$, and $120 \mathrm{ppm} \mathrm{Hg}$. After cyanide leaching of the feed at $\mathrm{pH} 10.4,80 \%$ of the total mercury (in the form of cinnabar and metacinnabar) goes to the tailings dam. In this research, separation of mercury from the tailings by flotation was investigated. The effects of collector type and dosage, $\mathrm{pH}$, and the number of cleaner stages were studied. The results showed that after two stages of cleaning a $40-62 \%$ recovery of $\mathrm{Hg}$ at a grade of $14.3 \% \mathrm{Hg}$ is attainable. Recycle water from a test in which $50 \mathrm{~g} / \mathrm{t}$ amyl xanthate and $30 \mathrm{~g} / \mathrm{t}$ pine oil was used in the flotation stage showed no adverse effect on the leaching and adsorption of gold onto activated carbon.

Keywords

mercury removal, tailings, leaching, flotation, Agh-Darreh.

\section{Introduction}

Mercury, most commonly found in the nature as the mineral cinnabar ( $\mathrm{HgS})$, is a hazardous substance because of its mobility and toxicity (Kyle et al., 2012). Roasting is the wellestablished treatment method for mercury ores, in which the sulphur is burned and volatilized and mercury recovered subsequently by cooling and condensation. However, for low-grade ores, flotation is mainly applied for primary concentration due to its comparatively low costs, low environmental hazards, and flexibility regarding feed variations (Bulatovic, 2007). Particularly, cinnabar can be easily recovered by flotation using pine oil and a collector such as xanthate (Bulatovic, 2007; Crozier, 1991). Floatability of cinnabar is reduced due to surface oxidation when it is exposed to the atmosphere after crushing. This problem can be eliminated by adding copper sulphate and lead nitrate or acetate. The best $\mathrm{pH}$ for cinnabar flotation is in the range of 6.5 to 8.5 according to Erspamer and Wells, (1954), who reported that cinnabar and stibnite can be floated with long-chain xanthate collectors and an alcohol frother, with cumulative recoveries of $97.8 \%$ and $94.7 \%$, respectively. Lead acetate was used as an activator.
If flotation is carried out before or after leaching, it might contaminate the recycle water and have adverse effects on the leaching and adsorption of gold. Increased flotation reagent dosages could exacerbate these effect (Salarirad and Behnamfard, 2010, 2011). Salarirad and Behnamfard investigated the effect of flotation reagents on gold leaching and sorption kinetics, as well as the loading capacity of gold onto activated carbon. They showed that flotation reagents had a detrimental effect on the leaching process, and such effects increased with increasing reagent concentrations. They also reported that the adsorption of organic material on activated carbon influences the gold sorption kinetics, but does not have a significant effect on the loading capacity. In another investigation, Salarirad and Behnamfard (2010, 2011) showed that the kinetic constant of the leaching rate was reduced by $46 \%$ using 20 ppm PIBX, compared to when the collector is not used.

Gold ore from the Agh-Darreh deposit, located in Takab, Iran, contains silver and mercury. The ore from the mine is crushed and milled in closed circuit $\left(P_{80}=53 \mu \mathrm{m}\right)$ and then treated by carbon in leach (CIL) (Figure 1). The leaching reagent is cyanide and the $\mathrm{pH}$ of the pulp is normally adjusted to a value of 10.5-11. Leached gold, silver, and mercury are adsorbed onto the activated carbon, which is transferred to acid washing and elution columns for desorption of precious metals by sodium hydroxide and sodium cyanide. After elution, the pregnant solution containing gold,

* Department of Mining Engineering Nasr Bridge, Tarbiat Modares University, Tehran, Iran.

+ Pouyazarcan Agh-Darreh Company, Tehran, Iran.

¥ Corrosponding Author, Department of Mining Engineering Nasr Bridge, Tarbiat Modares University, Tehran, Iran.

(c) The Southern African Institute of Mining and Metallurgy, 2017. ISSN 2225-6253. Paper received May 2015; revised paper received Jul. 2016. 


\section{Flotation of mercury from the tailings of the Agh-Darreh gold processing plant}

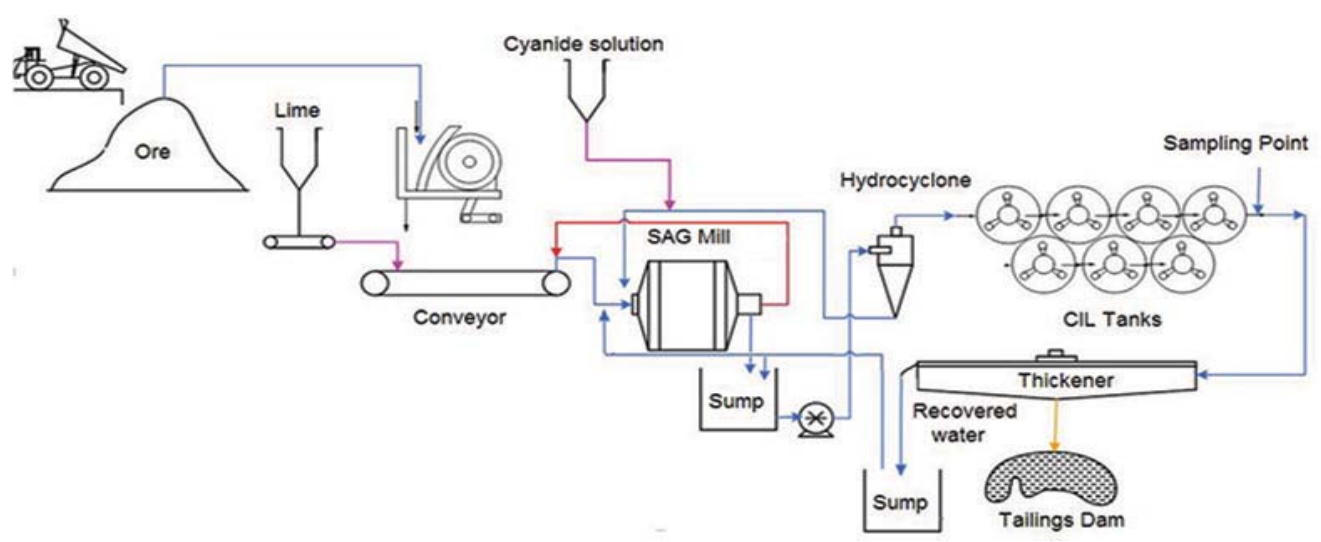

Figure 1-Agh-Darreh gold processing plant flow sheet

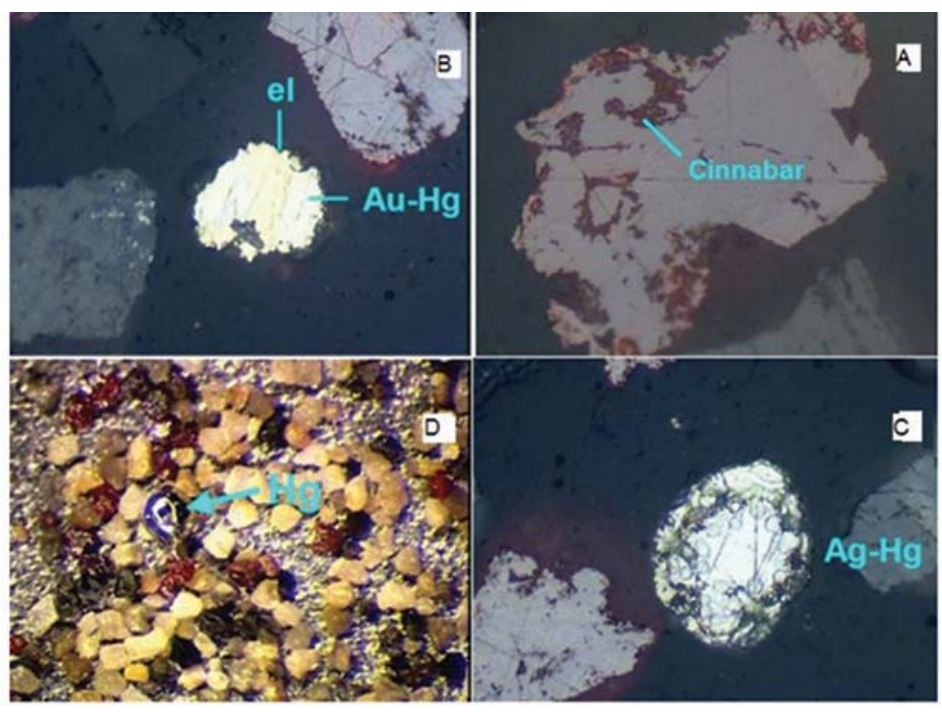

Figure 2-Mercury in form of (A) cinnabar (free and enclosed in other minerals), (B and C) alloys of gold, silver, and mercury, and (D) metallic mercury (AMTEL Institute, 2008)

silver, and mercury is transferred to a tank in which mercury is precipitated using sodium sulphide. After mercury precipitation, the solution containing gold and silver is transferred to electrowinning. Only $10 \%$ of the total mercury (85-150) ppm is recovered (AMTEL Institute, 2008), since just 20\% of the total mercury is leached by cyanide in the leaching circuit and about $50 \%$ of the dissolved mercury is adsorbed onto activated carbon. Unleached mercury, which comprises mainly cinnabar and metacinnabar, goes to the tailing dam. This is neither environmentally nor economically acceptable. In this research, flotation experiments were conducted on the leach tailing from Agh-Darreh gold processing plant in order to recover the mercury. The effect of flotation reagents on gold leaching and adsorption on activated carbon was also studied to investigate the technical possibility of the proposed flotation process.

\section{Materials and methods}

\section{Flotation material}

The sampling point for feed for flotation experiments is shown in the flow sheet in Figure 1. Firstly, the distribution of mercury in various size fractions of the sample was determined. It was observed that most of the mercury $(79.08 \%)$ resides in the $-37 \mu \mathrm{m}$ size fraction. Mineralogical analysis indicated that silicates and carbonates are the most important components of the ore, and less than 5\% consists of arsenates and oxides. Sulphides contribute to less than $0.1 \%$ of the ore (AMTEL Institute, 2008). The main silicate minerals are quartz, muscovite, kaolinite, and smectite. Carbonate minerals include calcite and dolomite, and the most important sulphide mineral is cinnabar. Mercury occurs in the form of cinnabar, metacinnabar, alloys of mercury with silver and gold, and metallic mercury (AMTEL Institute, 2008). Some grains of cinnabar and mercury alloys are shown in Figure 2.

\section{Flotation experiments}

The effects of the main collector, number of cleaning stages, and $\mathrm{pH}$ were studied. Cleaner experiments were done in a 5.4 litre laboratory flotation cell, while other experiments were done in a 1.4 litre cell. 


\section{Flotation of mercury from the tailings of the Agh-Darreh gold processing plant}

\section{Collector selection}

Potassium ethyl xanthate (PEX), potassium amyl xanthate (PAX), and sodium isobutyl xanthate (SIBX) were used as collectors. To compare the performance of the three collectors, flotation conditions were selected to be identical, as tabulated in Table I. To perform the experiments, a sample with $30 \%$ solids was prepared. Then, the pulp pH was reached reduced to 9.8 by the addition of sulphuric acid. Finally, each experiment was conducted in two steps and at each step concentrates were collected twice. Concentrates and tailings were weighed and dried at $60^{\circ} \mathrm{C}$ and the mercury contents determined by atomic absorption spectroscopy (AAS). The number of steps for adding the collector and the best times for concentrate removal were determined in preliminary tests.

\section{Effect of $\mathrm{pH}$}

Lime was used for $\mathrm{pH}$ adjustment. Preliminary tests showed that the formation of pine oil froth is very poor and the froth is not stable at $\mathrm{pH}<8$, even at high doses, and therefore the recovery was very low. MIBC and alcohol frothers were also used, but froth formation with these frothers was also very poor, so the experiments were performed at $\mathrm{pH}>8$ using pine oil, as shown in Figure 3.

\section{Cleaner experiments}

In most cases, concentrate from the rougher flotation stage is not considered as the final concentrate and several cleaning stages are necessary to produce a final concentrate. Experiments were performed to determine the number of cleaner stages and the final concentrate grade with one- and two-stage cleaning.

\section{Effect of flotation reagents on leaching and adsorption of gold onto activated carbon}

These experiments were carried out in two series as shown in Figure 4. In first stage, carbon in leach (CIL) experiments using fresh water and water recovered from flotation tests were conducted. In the second stage, adsorption experiments were carried out using the carbon from the previous stage (carbon that had and had not been exposed to flotation reagents).

> Stage 1: CIL experiments - In the first stage, a flotation experiment was done with $50 \mathrm{~g} / \mathrm{t}$ of PAX and $30 \mathrm{~g} / \mathrm{t}$ of pine oil at $\mathrm{pH} 10$. At the end of the experiment, the flotation tail was filtered and its water collected for the CIL experiment. To perform the CIL experiments, $2 \mathrm{~kg}$ of sample ( $1.420 \mathrm{~g} / \mathrm{t}$ gold) was ground to a $d_{80}$ of $60 \mu \mathrm{m}$ and divided into three equal parts. One part was kept as a control sample and the other two samples were poured into bottles. Experiments were done at $40 \%$ solids and $\mathrm{pH} 10.5$ with fresh water used in the plant (experiment 1) and water recovered from the flotation tailings (experiment 2). The properties of fresh water and recovered water are shown in Table II. Sodium cyanide $(0.3 \mathrm{~g})$ was added and the bottles were placed on a bottle roll apparatus. After 5 minutes, $5 \mathrm{~g}$ of carbon was added to each bottle, and after 24 hours the bottles were removed from the apparatus. The carbon from each bottle was separated by sieving and two samples from each bottle were prepared for analysis of solution and solid.

Table I

Flotation tests conditions for comparing collectors performance

\begin{tabular}{|l|c|c|c|}
\hline $\begin{array}{l}\text { Flotation } \\
\text { step }\end{array}$ & Reagents & $\begin{array}{c}\text { Concentrate } \\
\text { collection }\end{array}$ & $\begin{array}{c}\text { Cumulative } \\
\text { time (min) }\end{array}$ \\
\hline \multirow{3}{*}{ First step } & Collector $(35 \mathrm{~g} / \mathrm{t})$ & - & 0 \\
\cline { 2 - 4 } & Pine oil $(30 \mathrm{~g} / \mathrm{t})$ & - & 2 \\
\cline { 2 - 4 } & - & Concentrate 1 & $4-8$ \\
\cline { 2 - 4 } & - & Concentrate 2 & $8-12$ \\
\hline Second step & Collector $(15 \mathrm{~g} / \mathrm{t})$ & - & 12 \\
\cline { 2 - 4 } & - & Concentrate 3 & $14-17$ \\
\cline { 2 - 4 } & - & Concentrate 4 & $17-20$ \\
\hline
\end{tabular}

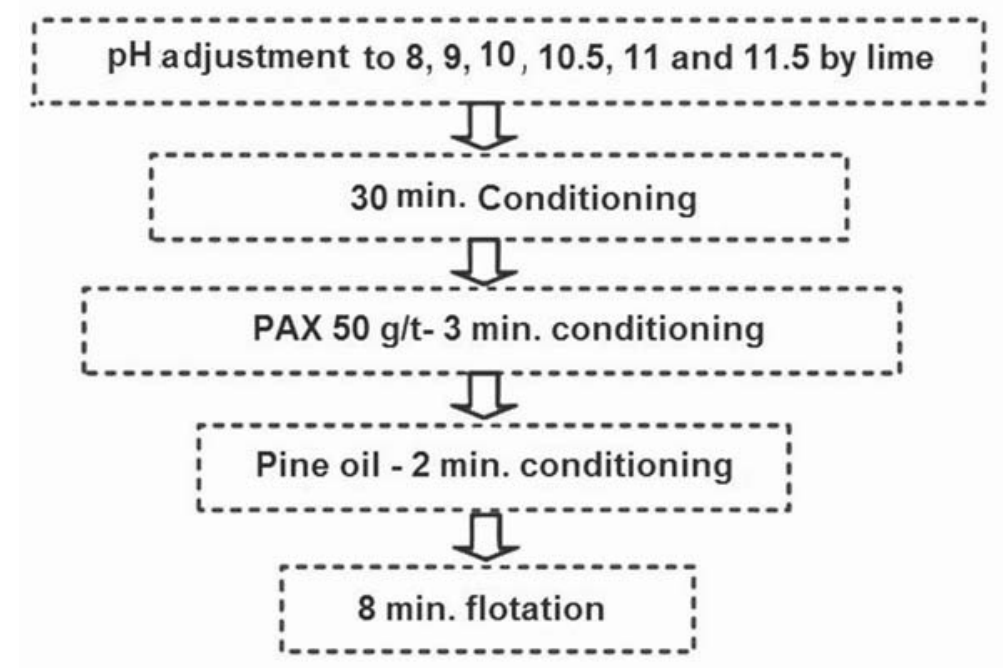

Figure 3-Experiments conducted to investigate the effect of $\mathrm{pH}$ 


\section{Flotation of mercury from the tailings of the Agh-Darreh gold processing plant}

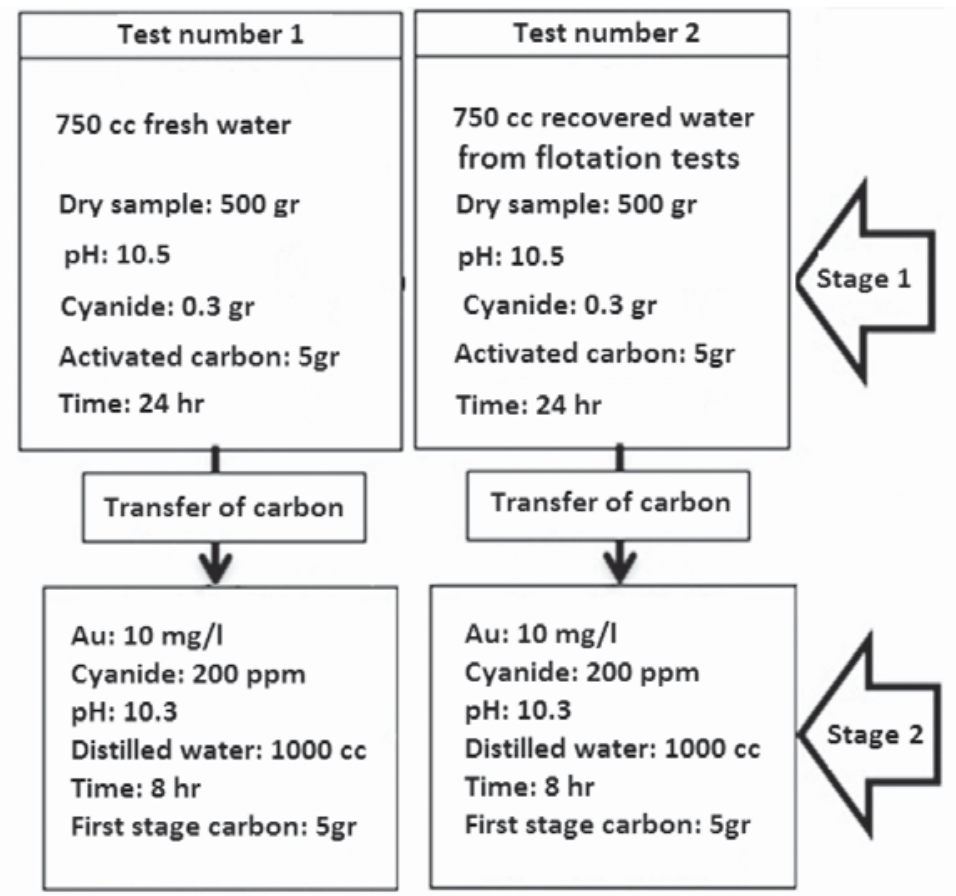

Figure 4-Experiments to investigate the effect of flotation reagents on leaching and adsorption of gold onto activated carbon

Table II

Characteristics of fresh water and recovered water from flotation tailings

\begin{tabular}{|c|c|c|c|c|c|c|c|c|c|c|c|}
\hline Water type & $\begin{array}{l}\text { PAX } \\
\text { ppm }\end{array}$ & $\begin{array}{c}\mathrm{Pb} \\
\mathrm{ppm}\end{array}$ & $\begin{array}{c}\mathrm{Ag} \\
\mathrm{ppm}\end{array}$ & $\begin{array}{c}\mathrm{Au} \\
\mathrm{ppm}\end{array}$ & $\begin{array}{c}\mathrm{Sb} \\
\mathrm{ppm}\end{array}$ & $\begin{array}{c}\mathrm{Fe} \\
\mathrm{ppm}\end{array}$ & $\begin{array}{c}\mathrm{Zn} \\
\mathrm{ppm}\end{array}$ & $\begin{array}{c}\mathrm{Hg} \\
\mathrm{ppm}\end{array}$ & $\begin{array}{c}\text { CN } \\
\text { ppm }\end{array}$ & $\begin{array}{c}\mathrm{EC} \\
\mathrm{ms} / \mathrm{m}\end{array}$ & $\mathrm{pH}$ \\
\hline $\begin{array}{l}\text { Fresh water } \\
\text { Recovered water }\end{array}$ & $\begin{array}{c}0 \\
2.4\end{array}$ & $\begin{array}{c}0 \\
0.06\end{array}$ & $\begin{array}{c}0 \\
0.07\end{array}$ & $\begin{array}{c}0 \\
0.005\end{array}$ & $\begin{array}{l}0.71 \\
1.16\end{array}$ & $\begin{array}{c}1 \\
3.2\end{array}$ & $\begin{array}{c}0 \\
37.5\end{array}$ & $\begin{array}{c}0 \\
5.5\end{array}$ & $\begin{array}{c}0 \\
6.8\end{array}$ & $\begin{array}{l}0.48 \\
1.46\end{array}$ & $\begin{array}{l}7.8 \\
9.85\end{array}$ \\
\hline
\end{tabular}

- Stage 2: determination of adsorption kinetics-To study the adsorption kinetics, two bottles were prepared, each containing one litre of solution with $10 \mathrm{~g} / \mathrm{t}$ of gold, $200 \mathrm{~g} / \mathrm{t}$ of cyanide at $\mathrm{pH} 10.3$, and the carbon from the first stage with the same experiment number (Figure 4). The bottles were then placed on a bottle roll apparatus for 24 hours at a rolling speed of $30 \mathrm{rpm}$. Samples of $50 \mathrm{ml}$ were taken throughout the course of the experiments at predetermined times.

\section{Analysis method}

Solutions were directly analysed for gold by atomic absorption spectrometry (AAS) (Varian Model AA240). Mercury analysis was done by dissolution with aqua regia followed by extraction by diisobutyl ketone (DIBK) and AAS analysis. Other elements were measured by AAS. The PAX concentration in the recovered water was determined by UV spectrophotometry. Electrical conductivity was determined by conductivity meter.

\section{Determination of kinetic rate constant}

The fouling effect of flotation reagents on the kinetics of gold adsorption can be evaluated through the adsorption kinetic constant $k$ (Equation [1]).

$$
\Delta[A u]_{c}^{t}=k[A u]_{s}^{t} t^{n}
$$

Equation [1] can also be expressed in the linearized logarithmic form:

$$
\log \left(\Delta[A u]_{c}^{t} /[A u]_{s}^{t}\right)=\log k+n \log t
$$

where $\Delta[A u]_{c}^{t}$ is the change in gold content adsorbed onto carbon from time zero to time $t(\mathrm{~g} / \mathrm{t}),[A u]_{s}^{t}$ is the gold concentration in solution at time $t(\mathrm{mg} / \mathrm{L}), n$ is an empirical constant dependent on the characteristics of the activated carbon, $k$ is the kinetic rate constant $\left(h^{-1}\right)$, and $t$ is the adsorption time $(\mathrm{h})$.

By plotting $\log \left(\Delta[A u]_{c}^{t} /[A u]_{s}^{t} v s . \log t\right.$, a straight line is obtained and therefore the $k$ value can be easily determined from the intercept. All experiments were performed in triplicate and the mean $k$ values were taken into account.

\section{Results and discussion}

\section{Collector selection}

Results of experiments comparing the collectors are shown in Figure 5. After four stages of concentrate collection, PAX shows better grades and recoveries. However, in the first 


\section{Flotation of mercury from the tailings of the Agh-Darreh gold processing plant}

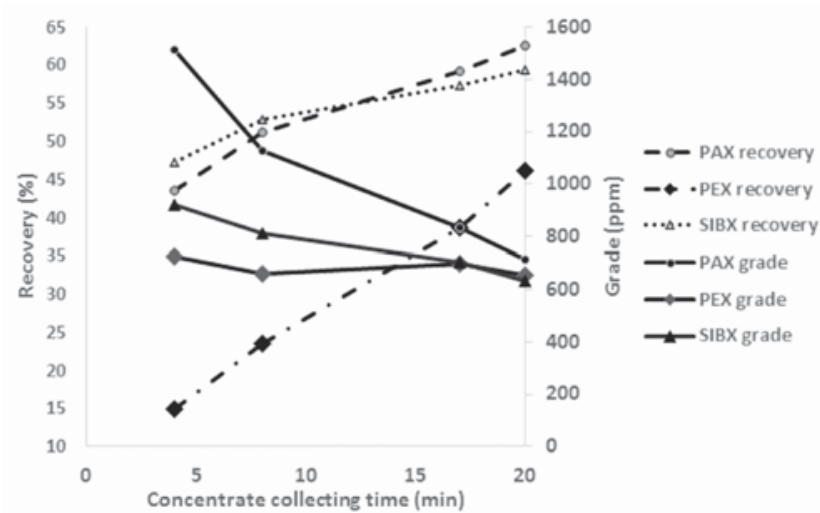

Figure 5-Effect of collector type on mercury recovery to the flotation concentrate

collected concentrates, the rate of flotation with SIBX is much higher than with PAX (mercury recovery of $51.26 \%$ for SIBX compared to $43.48 \%$ for PAX). Tails from flotation with PAX were sieved and the mercury in each size fraction determined. The highest mercury grades in the feed and in the flotation tailings was in the $-37 \mu \mathrm{m}$ fraction; $79.08 \%$ and $80.4 \%$ respectively. Maximum mercury recovery was obtained in the $+37-53 \mu \mathrm{m}$ fraction, with $97 \mathrm{ppm}$ mercury in the feed reduced to $30.5 \mathrm{ppm}$ in the tailings. In the $-37 \mu \mathrm{m}$ fraction of the tailings, the mercury grade was $53 \mathrm{ppm}$, compared with $104.5 \mathrm{ppm}$ in the feed.

\section{Cleaner experiments}

\section{Flotation with single-stage cleaning}

In this experiment, the mercury grade of the concentrate reached $6400 \mathrm{ppm}$, from $153 \mathrm{ppm}$ in the feed, an enrichment ratio of 42 . Recoveries of mercury to the final tail and concentrate were $42.75 \%$ and $45.07 \%$, respectively. Recovery of mercury to the tailings of the first-stage cleaner was $12.18 \%$, which can be returned to the flotation circuit.

\section{Flotation with two-stage cleaning}

Figure 5 shows that after two steps of cleaning, the mercury content of the concentrate was $86667 \mathrm{ppm}$, compared with $84.5 \mathrm{ppm}$ in the feed, an enrichment ratio of 1025 . This experiment was repeated with the same conditions as the previous experiment; except that the leach tailings samples were collected on different days. The results of the repeat experiment confirmed the results presented in Figure 6. The mercury grade in replicate feed sample was $113.6 \mathrm{ppm}$, and $143000 \mathrm{ppm}$ in the concentrate (enrichment ratio 1258).

\section{Effect of $\mathrm{pH}$}

The effect of pH on mercury recovery and grade is shown in Figure 7 . In these experiments, the highest grade and lowest recovery was at $\mathrm{pH} \mathrm{9}$, and the highest recovery and lowest grade at $\mathrm{pH} 10$. As recovery has the most influence on the process economics, and based on previous experiments in which the mercury assay after two cleaner stages reached 143000 ppm and was ideal for subsequent steps, pH 10 was selected. Recovery was reduced at $\mathrm{pH}>10.5$. At lower $\mathrm{pH}$ values, the stability of pine oil froth is reduced.

\section{Effect of flotation reagents on leaching and adsorption of gold onto activated carbon}

\section{Carbon in leach experiments}

The results of the CIL experiments are shown in Table III. In

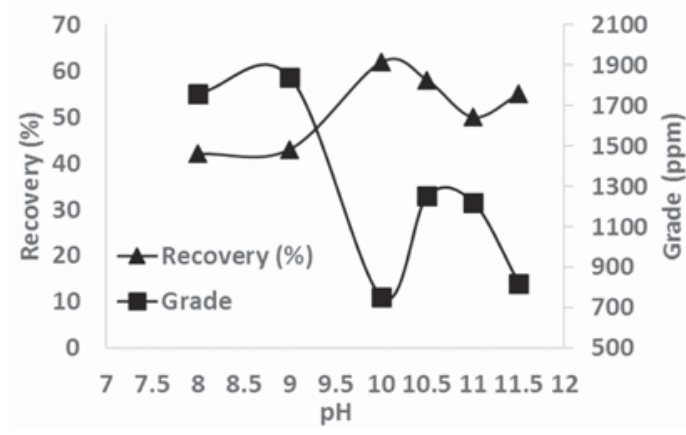

Figure 7-Effect of $\mathrm{pH}$ on recovery and grade

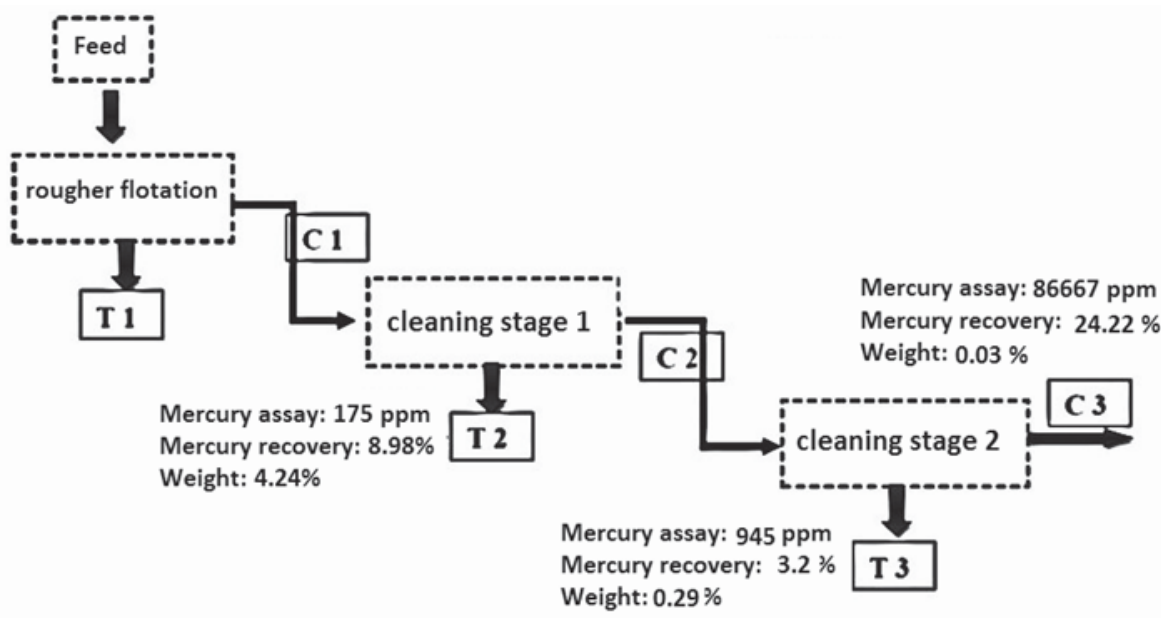




\section{Flotation of mercury from the tailings of the Agh-Darreh gold processing plant}

\begin{tabular}{|c|c|c|c|c|}
\hline \multicolumn{5}{|c|}{$\begin{array}{l}\text { Table III } \\
\text { Results of carbon in leach experiments }\end{array}$} \\
\hline $\begin{array}{l}\text { Experiment } \\
\text { No. }\end{array}$ & $\begin{array}{c}\text { Solid } \\
\text { assay (ppm) }\end{array}$ & $\begin{array}{l}\text { Liquid } \\
\text { assay (ppm) }\end{array}$ & $\begin{array}{c}\text { Leaching } \\
\text { recovery (\%) }\end{array}$ & $\begin{array}{l}\text { Adsorption } \\
\text { recovery (\%) }\end{array}$ \\
\hline 1 & 0.133 & Below 0.005 & 90.63 & 99.4 \\
\hline 2 & 0.134 & Below 0.005 & 90.56 & 99.4 \\
\hline
\end{tabular}

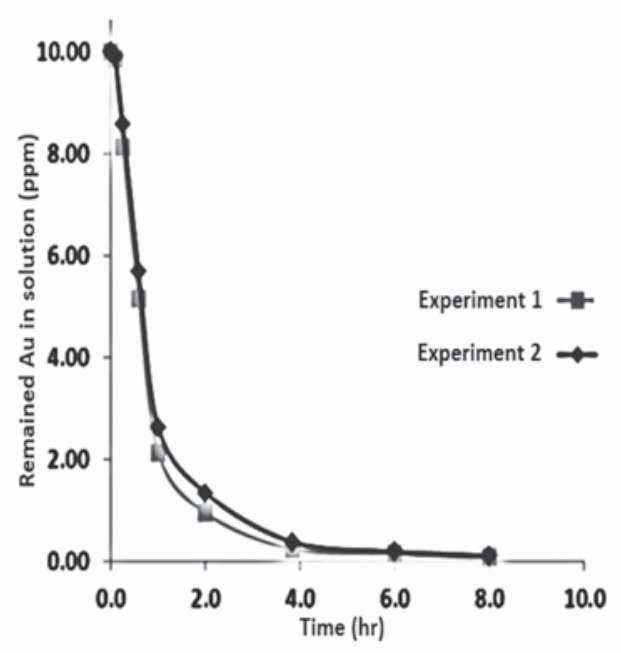

Figure 8-Variation of gold remaining in solution versus time for adsorption experiments. Experiment 1 with non-contaminated carbon, and experiment 2 with contaminated carbon

both experiments, gold remaining in the solution is less than the detection limit of the instrument. More than $99 \%$ of the dissolved gold was absorbed by activated carbon in both experiments. These results showed that the recovered flotation water at reagent dosages used in the flotation experiments had no effect on leaching of gold.

\section{Adsorption experiments}

The adsorption patterns of gold onto activated carbon in experiments with fresh and recovered water, are shown in Figure 8. The main difference between the two graphs is the initial slope; the adsorption kinetics for the carbon that was not in contact with flotation reagents were faster than for the carbon that was in contact with flotation reagents. The plots of $\log \left(\Delta[A u]_{c}^{t} /[A u]_{S}^{t}\right.$ versus $\log t$ for experiments 1 and 2 were drawn and the $k$ values for the experiments were calculated as 458 and $332 h^{-1}$ respectively. This indicates that the dosage of collector and frother had little impact on the kinetics of gold adsorption. Both kinetic constants were higher than minimum practical level, which is $80-100 h^{-1}$ (Salarirad and Behnamfard, 2011). The limited effect of flotation reagents on the adsorption kinetics may be due to the deportment of a large quantity of them into froth phase (the concentrate), while the recovered water is recycled from the leach tailing. The degradation of reagents during flotation could be an additional reason for their reduced fouling properties (Molina et al., 2013).

\section{Conclusion}

Flotation experiments were conducted to investigate the recovery of mercury from leach tailings. With two stages of cleaning, the maximum mercury recovery and concentrate grade were $62 \%$ and $14.3 \%$, respectively, with an enrichment ratio of over 1000 . The flotation concentrate can be roasted and mercury recovered by cooling and condensation.

Further experiments were performed to investigate the effect of flotation reagents on gold leaching and adsorption, as in the final flow sheet the water would be recovered from the proposed flotation circuit and used in the gold leaching and adsorption sections. The reagents used in the flotation tests had no significant effects on the gold leaching and adsorption processes at the dosages used in the experiments. Particularly, if the water is recovered from the tailing of the flotation cells, the effects of reagents are predicted to be negligible.

\section{Acknowledgements}

All laboratory personnel of Agh Dareh gold processing plant are thanked for their assistance.

\section{References}

AMTEL Institute. 2008. Distribution of gold and mercury in feed hydrocyclone products of Agh-Darreh.

Bulatovic, S.M. 2007. Handbook of Flotation Reagents: Chemistry, Theory and Practice: Volume 1: Flotation of Sulfide Ores. Elsevier.

CRozier, R. 1991. Sulphide collector mineral bonding and the mechanism of flotation. Minerals Engineering, vol. 4, no. 7. pp. 839-858.

ERSPAMER, E. and Wells, R. 1956. Selective extraction of mercury and antimony from cinnabar-stibnite ore. US Bureau of Mines.

KyLE, J. Breuer, P.L., Bunney, K.G., and MAy, P.M. 2012. Review of trace toxic elements ( $\mathrm{Pb}, \mathrm{Cd}, \mathrm{Hg}, \mathrm{As}, \mathrm{Sb}, \mathrm{Bi}, \mathrm{Se}, \mathrm{Te})$ and their deportment in gold processing: Part II: Deportment in gold ore processing by cyanidation. Hydrometallurgy, vol. 111. pp. 10-21.

Molina, G.C., CAyo, H.C., Rodrigues, M.A.S., and Bernades, A.M. 2013. Sodium isopropyl xanthate degradation by advanced oxidation processes. Minerals Engineering, vol. 45. pp. 88-93.

Salarirad, M.M. and Behnamfard, A. 2011. Fouling effect of different flotation and dewatering reagents on activated carbon and sorption kinetics of gold. Hydrometallurgy, vol. 109, no. 1. pp. 23-28.

Salarirad, M.M. and Behnamfard, A. 2010. The effect of flotation reagents on cyanidation, loading capacity and sorption kinetics of gold onto activated carbon. Hydrometallurgy, vol. 105, no. 1. pp. 47-53. 